\title{
PENEMUAN SEBUAH CANDI BATA DI DAERAH PANTURA JAWA TENGAH
}

\section{THE FINDING OF BRICK CONSTRUCTED TEMPLE IN THE NORTHERN COASTAL OF CENTRAL JAVA}

\author{
T.M. Rita Istari \\ Balai Arkeologi Yogyakarta
}

\begin{abstract}
The discovery of Kayen Temple in Pati Regency adds the numbers of brick-made temples in Central Java. Balai Arkeologi Yogyakarta conducted previously, a research in areas near Borobudur on assumption that these areas were the cultural and political center of ancient civilization and a fact that most temples are located near Borobudur Temple within 15 kilometers radius. Those temples were either made from andesites or bricks. Temples made from bricks are often discovered in small size, they show that bricks were one of popular building materials that used for temples other than andesites. Kayen Temple is considered as a rare discovery of brick-made temple in the Northern Coast of Central Java. Pati Regency profoundly known as destination for pilgrimage because of its Islamic Heritage also has many destination for Classic Hinduism Heritage
\end{abstract}

Keywords:Temple, Brick, Hindu Era

\begin{abstract}
ABSTRAK
Penemuan Candi Kayen di Kabupaten Pati, menambah jumlah bangunan candi berbahan bata di Jawa Tengah. Penelitian yang pernah dilakukan Balai Arkeologi Yogyakarta sebelumnya, dilakukan di kawasan sekitar Borobudur. Dipilihnya kawasan ini dengan asumsi merupakan salah satu pusat budaya dan politik masa lalu di Jawa Tengah. Diketahui pula bahwa sebagian besar situs candi terkonsentrasi di sekitar Candi Borobudur pada radius $15 \mathrm{~km}$. Candi-candi tersebut selain dibuat dari bahan batu andesit, juga banyak dijumpai situs candi-candi bata. Candi-candi bata berlatar belakang agama Hindu dan Buddha belum banyak yang ditemukan dalam ukuran besar, melainkan berukuran relatif kecil. Hal ini menyiratkan bukan masalah besar kecilnya candi, tetapi menunjukkan bahwa bata merupakan salah satu material yang sering dipakai untuk pendirian bangunan suci selain batu andesit. Candi bata dari Kayen merupakan temuan yang penting dan masih langka di kawasan pantura Jawa Tengah. Kabupaten Pati selama ini dikenal sebagai kota wisata religi, dengan banyaknya tingalan-tinggalan Masa Islam, tetapi ternyata mempunyai pula bangunan candi Masa Klasik/Hindu yang dapat menambah aset wisata budaya daerah.
\end{abstract}

Kata kunci: Candi, Bata, Masa Hindu

\section{PENDAHULUAN}

Candi Kayen terletak di Dusun Buloh, Desa Kayen, Kecamatan Kayen, Kabupaten Pati, berada pada koordinat $111^{\circ} 00^{\prime} 17.0^{\prime \prime}$ Bujur Timur dan $06^{\circ} 54^{\prime} 31.8^{\prime \prime}$ Lintang Selatan. Situs Kayen berada di dataran alluvial yang cukup datar dan luas. Hal ini dengan ditandai pemanfaatan lokasi sebagai permukiman dan persawahan. Kondisi lingkungan cukup 
subur didukung oleh keberadaan Sungai Sombron yang berhulu di Pegunungan Kendeng, dan bermuara di Sungai Tanjang Pati. Kabupaten Pati terdiri atas 8 Kecamatan, yaitu: Kayen, Sukolilo, Dukuhseti, Tayu, Pati, Trangkil, Juwono, dan Margorejo.

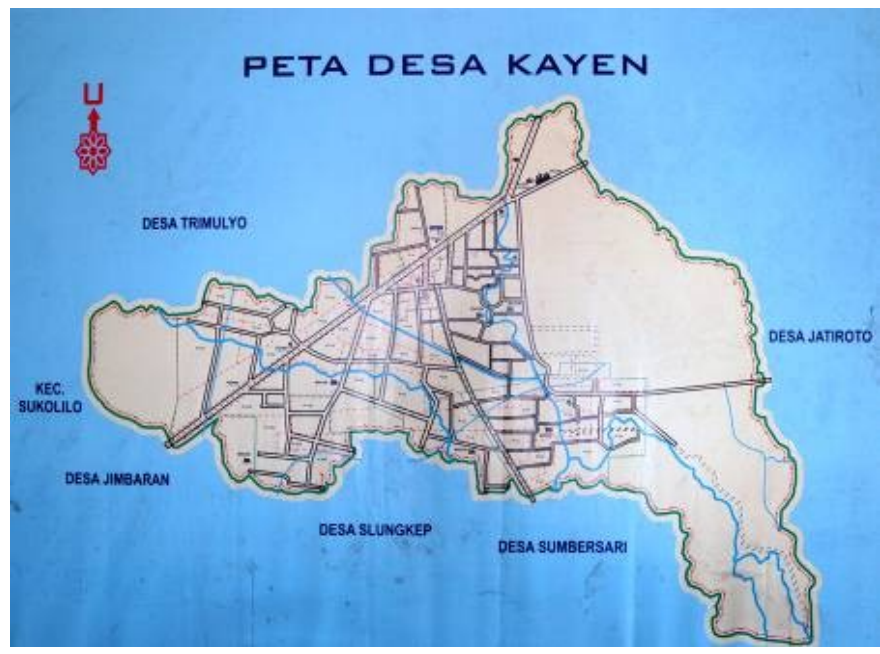

Gambar1. Peta Desa Kayen, tempat penemuan candi

Penelitian terhadap Candi Kayen berawal dari laporan Ketua Pengurus pembangunan musholla Bapak Nur Rohmat, yang berencana membangun musholla yang berada di tengah lahan persawahan Desa Tohyaning. Pembangunan musholla itu bertujuan sebagai tempat beribadah bagi para peziarah makam Ki Gede Miyono atau disebut juga dengan nama Ki Ageng Dharmoyono, yang dianggap sebagai cikal bakal masyarakat Desa Kayen. Pada waktu pembangunan musholla tersebut dilaksanakan, ditemukan struktur bangunan dan runtuhan bata berukuran besar. Selanjutnya pembangunan tersebut digeser sejauh 5 meter dari lokasi stuktur bata, dan sesudah fondasi bangunan musholla selesai dibuat, maka untuk sementara pembangunan dihentikan. Dari runtuhan bata-bata yang masih utuh kemudian dipindahkan ke lokasi makam Ki Gede Miyono untuk merenovasi makam tersebut.

Penemuan ini dilaporkan dan ditindaklanjuti oleh Balai Pelestarian Peninggalan Purbakala (BP3) Jawa Tengah pada bulan Agustus 2010. Berdasarkan peninjauan BP3 Jawa Tengah diperoleh hasil, bahwa di wilayah Desa Kayen terdapat tinggalan Benda Cagar Budaya (BCB) yang bernilai arkeologis dan historis berupa:

1. Struktur bata yang masih intact. Pada saat dilakukan peninjauan, keadaan temuan sebagian masih berada di bawah permukaan tanah, dan sebagian sudah diangkat. Walau belum seluruh temuan terpendam dapat ditampakkan, luas area temuan diperkirakan mencapai $30 \mathrm{~m}$ x $40 \mathrm{~m}$.

2. Temuan serta.

Temuan lain yang dilaporkan berasal dari area temuan struktur bata adalah Arca Siwa Mahakala, peripih, keramik, dan artefak berbahan perunggu.

Sebagai tindak lanjut rekomendasi hasil peninjauan, dilakukan kegiatan penelitian yang lebih intensif berupa research excavation pada bulan September 2011 oleh Balai Arkeologi Yogyakarta. Hasil penelitian berupa temuan dua buah struktur bangunan candi berbahan bata. Selain data arsitektural juga ditemukan data artefaktual berupa pendukung struktur (ornamen) bangunan candi berupa antefiks polos dan kemuncak (Istari. 2011).

Berdasarkan penelitian yang sudah dilakukan, dan untuk mengetahui lebih lanjut tentang Candi Kayen, maka permasalahan yang diajukan dalam penelitian ini adalah:

1. Bagaimana karakteristik dan arsitektur Candi Kayen?

2. Kapan kronologi Candi Kayen? 
Salah satu pedoman yang merupakan konsep mendirikan suatu bangunan suci seperti yang disebutkan dalam Kitab Manasara (buku pedoman dari India Selatan tentang pembuatan seni bangunan) adalah, bahwa bangunan suci atau candi sebaiknya didirikan di puncak bukit, di lereng gunung, di hutan, di lembah, dan di dekat tempat-tempat yang sering disinggahi para dewa. Namun demikian, candi juga dapat didirikan dekat dengan air seperti danau, sungai, mata air muara sungai dan laut (Kramrisch, 1949). Di samping itu tentunya ada pula syarat-syarat yang diwajibkan dalam pembangunan suatu bangunan suci, tidak hanya yang berkaitan dengan konstruksi bangunan saja, tetapi juga meliputi lahan, jenis tanah, dan lingkungannya.

Menurut Soekmono dalam disertasinya yang berjudul "Candi. Fungsi dan Pengertiannya" (1974), candi adalah bangunan suci tempat pemujaan dewa. Candi melambangkan Mahameru, yaitu gunung yang dianggap menyerupai alam semesta. Bangunan candi biasanya terdiri atas tiga bagian yang melambangkan tiga dunia yaitu kaki (bhurloka), tubuh (bhuwarloka), dan atap (swarloka) (Boechari, 1978)). Sebagai bangunan suci keagamaan tentunya diperlukan syarat-syarat khusus dalam pendiriannya. Disebutkan dalam kitab Mânasâra-Çilpaçastra - kitab yang berisi aturan-aturan pembangunan kuil di India - bahwa sebelum bangunan kuil didirikan maka sthapaka (arsitek pendeta) dan sthapati (arsitek perencana) harus lebih dahulu menilai kondisi dan kemampuan lahan yang akan dijadikan tempat berdirinya bangunan suci tersebut (Acharya, 1993). Dijelaskan juga bahwa lahan tempat berdirinya suatu bangunan kuil dinilai sangat penting, bahkan lebih penting dari bangunan suci itu sendiri (Mundardjito, 1993). Selain pemilihan lokasi dan aturan-aturan lain dalam pembangunan suatu bangunan suci diperlukan juga syarat-syarat tertentu dalam pemilihan bahan bangunannya, tentunya harus dipilih bahan yang tahan lama seperti batu andesit, bata, atau batu putih. Meskipun secara teknis unsur bata lebih mudah rusak/rapuh dibandingkan batu andesit. Bangunan candi berbahan batu andesit maupun bata banyak dijumpai di wilayah pedalaman Jawa seperti di poros Kedu - Prambanan (Jawa Tengah DIY) dan Trowulan (Jawa Timur). Candi-candi bata yang terdapat di Jawa Tengah tidak sebanyak dan semegah candi-candi bata di Jawa Timur. Sebagian besar tinggal sisasisanya berupa struktur bata maupun fragmen-fragmen bata lepas. Candi-candi bata di Jawa Timur hampir seluruhnya merupakan peninggalan Kerajaan Majapahit, yang masih menyisakan kemegahan hingga kini seperti Candi Wringin Lawang, Candi Brahu, Candi Bajang Ratu, dan Candi Sumur Upas. Banyaknya bangunan candi bata di kawasan pusat Kerajaan Mataram Kuna - kawasan di sekitar Candi Borobudur - menunjukkan bahwa teknologi pembuatan bata telah dikenal dengan baik pada masa itu (Tjahjono, 2003).

Penelitian menggunakan penalaran induktif dengan tipe penelitian deskriptif. Pengumpulan data dilakukan melalui ekskavasi dan survei lingkungan sekitar situs. Untuk mengetahui faktor-faktor yang menyebabkan munculnya bangunan-bangunan candi dari bata atau yang menggunakan unsur bata di Jawa Tengah, maka unit analisisnya adalah situs dan lingkungannya.

Untuk mengetahui periodesasi candi, maka unit analisisnya meliputi pencarian pertanggalan relatif melalui analisis sumber tertulis (baik primer maupun sekunder) seperti angka tahun, perbandingan jenis huruf, perbandingan jenis atau langgam reliefnya. Selain itu juga akan dilakukan analisis pertanggalan radiocarbon (C14) apabila ditemukan sampel arang yang memadai.

Ekskavasi juga dilakukan, karena ekskavasi merupakan salah satu teknik pengumpulan data melalui penggalian tanah yang dilakukan secara sistematik, untuk mendapatkan data berupa tinggalan arkeologi dalam kondisi in situ. Berkenaan dengan kegiatan ekskavasi Candi Kayen ini, jenis ekskavasi yang digunakan adalah ekskavasi penelitian dan penyelamatan dikarenakan minimnya data arkeologi, serta untuk menyelamatkan Candi Kayen dari ancaman kerusakan. Sebelum ekskavasi dimulai, dilakukan kegiatan probing (penusukan) untuk penentuan lokasi maupun memperluas kotak gali. Alat yang digunakan adalah sebatang logam dengan diameter $2 \mathrm{~cm}$ dan panjang sekitar 1 meter. Alat ini ditusukkan ke tanah untuk mendapatkan indikasi 
keberadaan sisa struktur bangunan di dalam tanah. Dengan metode probing ini diharapkan penelitian akan lebih efisien dalam menggunakan waktu dan tenaga. Pelaksanaan ekskavasi, digunakan sistem box, yaitu dengan membuka kotak-kotak ekskavasi berukuran $2 \mathrm{~m} \times 2$ meter, dan diterapkan teknik spit, dengan interval kedalaman $20 \mathrm{~cm}$ setiap spitnya.

\section{PEROLEHAN DATA}

Sesuai dengan tujuan dan sasaran penelitian di Candi Kayen, maka dalam penelitian ini dibuka 8 kotak ekskavasi/penggalian. Kotak-kotak tersebut meneruskan kotak penggalian penelitian tahun lalu, yaitu menampakkan bangunan candi dan mencari keluasan situs Candi Kayen. Juga satu kotak ekskavasi yang dibuka dengan tujuan untuk membuktikan keberadaan Candi Perwara yang lain, yang sebelumnya diperkirakan ada 3 bangunan Candi Perwara.

\section{Kotak B5 U3}

Kotak ini dibuka untuk melacak pintu masuk Candi Induk. Kondisi permukaan tanah relatif datar dan tidak dijumpai indikasi temuan arkeologi. Kotak B5U3 berada di Candi Induk di sisi barat, yang sudah tampak setelah dilakukan ekskavasi pada tahun 2011.

Hasil akhir

1. Dijumpai 6 lapis bata yang masih intact dengan orientasi utara-selatan. Ukuran bata mempunyai panjang $39-41 \mathrm{~cm}$; lebar $23.5 \mathrm{~cm}-25 \mathrm{~cm}$; dan tebal $10 \mathrm{~cm}-$ $11,5 \mathrm{~cm}$.

2. Struktur bata yang menyerupai anak tangga sejumlah 3 susun, dan mempunyai lebar $51 \mathrm{~cm}$.

3. Batu isian pada Candi Induk berupa batu putih (limestone) dengan ukuran tebal $9 \mathrm{~cm}$ dan lebar $25 \mathrm{~cm}$.

4. Penggalian kotak dihentikan sampai spit 4 pada kedalaman $80 \mathrm{~cm}$.

\section{Kotak B5 U1}

Kotak ini dibuka untuk menampakkan profil sisi selatan Candi Induk. Kotak dibuka dengan ukuran $2 \mathrm{~m} \times 1 \mathrm{~m}$ pada sisi utara dengan orientasi timur-barat. Kotak B5U1 tepat berada pada pagar batas sementara situs Candi Kayen.

Hasil akhir

1. Dinding selatan kotak B5U1 dijumpai beberapa fragmen bata yang mengindikasikan sebagai runtuhan (non intact) berasal dari Candi Induk

2. Profil sisi selatan Candi Induk bagian sudut barat daya. Profil bata pada sisi selatan sebanyak 6 lapis bata dengan kondisi relatif masih intact. Ukuran bata mempunyai panjang antara $37 \mathrm{~cm}-39,5 \mathrm{~cm}$; lebar antara $23 \mathrm{~cm}-26 \mathrm{~cm}$; dan tebal antara $8 \mathrm{~cm}-10 \mathrm{~cm}$.

3. Penggalian kotak dihentikan pada spit 5 , dengan kedalaman $100 \mathrm{~cm}$.

\section{Kotak B4 U1}

Kotak ini dibuka untuk menampakkan profil sisi selatan Candi Induk. Kotak dibuka dengan ukuran $2 \mathrm{~m} \times 1 \mathrm{~m}$ sisi utara. Kondisi permukaan tanah hampir sama dengan kotak B5 U1.

Hasil akhir

1. Seperti di Kotak B5U1, di kotak B4U1 dinding selatan juga dijumpai beberapa fragmen bata yang cukup besar, merupakan runtuhan (non intact) yang berasal dari Candi Induk

2. Profil bata pada sisi selatan sebanyak 5 lapis bata dengan kondisi relatif masih intact. Ukuran bata mempunyai panjang antara $38 \mathrm{~cm}-39 \mathrm{~cm}$; lebar antara 23 $\mathrm{cm}-24 \mathrm{~cm}$; dan tebal antara $9.5 \mathrm{~cm}-10 \mathrm{~cm}$.

Penggalian kotak dihentikan pada spit 5, dengan kedalaman $100 \mathrm{~cm}$. 


\section{Kotak B10 U7}

Kotak ini dibuka untuk melacak keberadaan Candi Perwara sisi utara. Kotak B10 U7 berada di sebelah utara Candi Perwara yang sudah tampak pada penelitian sebelumnya, pada jarak 4 meter. Kondisi permukaan tanah sebelum dibuka berupa lahan yang ditanami kedelai dan tidak dijumpai indikasi data arkeologi.

Hasil akhir

Kotak B10 U7 dihentikan pada spit 3 dengan kedalaman $60 \mathrm{~cm}$, karena sudah tidak dijumpai indikasi Candi Perwara sisi utara seperti tujuan pembukaan kotak.

\section{Kotak B10 U3}

Kotak B10 U3 berada di sebelah utara struktur Candi Perwara yang sudah tampak pada penelitian sebelumnya. Pembukaan kotak ini bertujuan merunut Candi Perwara secara lebih utuh. Kondisi permukaan tanah sebelum dibuka berupa remukan bata-bata akibat galian sebelumnya, dan adanya struktur yang belum nampak jelas.

Hasil akhir

Penggalian kotak B10 U3 dihentikan pada spit 4 dengan kedalaman $80 \mathrm{~cm}$, karena sudut tenggara candi sudah ditemukan, dan indikasi untuk memperdalam kotak sudah tidak diperlukan lagi. Susunan bata berjumlah 5 buah secara vertikal, akibat tanah di sebelah utara ini melesak, jadi lebih rendah daripada struktur sebelah selatan.

\section{Kotak B10 U4}

Kotak ini terletak di tengah-tengah Candi Perwara, dengan kondisi permukaan tanah sebelum dibuka ditumbuhi rumput. Kotak ini dibuka dengan tujuan menampakkan bentuk struktur bangunan Candi Perwara yang sudah didapat struktur bangunan di sebelah dinding utara.

Hasil akhir

Kotak B10 U4 dihentikan pada spit 1 dengan kedalaman $20 \mathrm{~cm}$, karena struktur bangunan sebelah barat ternyata menyambung dengan struktur utara, dan adanya runtuhan bata-bata ke a rah barat.

\section{Kotak B10 U5}

Kotak B10 U5 berada di sebelah selatan struktur Candi Perwara yang sudah tampak pada penelitian sebelumnya. Pembukaan kotak ini bertujuan merunut Candi Perwara lebih utuh. Kondisi permukaan tanah sebelum dibuka berupa remukan bata akibat galian sebelumnya, dan adanya struktur yang belum nampak jelas.

Hasil akhir

Kotak B10 U5 dihentikan pada spit 3 dengan kedalaman $60 \mathrm{~cm}$, dan susunan bata masih tampak sebanyak 8 susun. Kondisi sisi selatan Candi Perwara ini kontur tanahnya lebih tinggi dari sebelah utara

\section{Hasil survei sekitar Candi Kayen}

\section{Situs Brati}

Lokasi Situs Brati berada di Dukuh Saploso, Desa Brati, pada koordinat S $06^{\circ} 54^{\prime}$ 41. 6"E $111^{\circ} 01^{\prime} 18.6$ ", dpl $37 \mathrm{~m}$ sebelah barat desa Brati. Lokasi situs secara kontur lebih tinggi dibandingkan daerah sekitarnya, menurut penduduk setempat lokasi ini disebut sawah mbotoan..Temuan berupa beberapa fragmen bata kuna, dengan ukuran tebal bata antara $8 \mathrm{~cm}-10 \mathrm{~cm}$ dan lebar bata $25 \mathrm{~cm}$. Ukuran panjang bata belum diketahui karena tidak dijumpai bata kuna yang masih utuh. 
Menurut pemilik lahan bahwa di lokasi ini masih dijumpai tatanan bata yang cukup rapi membujur utara-selatan, oleh karena itu dilakukan pembukaan tanah sedalam $\leq 10$ $\mathrm{cm}$ dan memang sudah dijumpai runtuhan bata -bata.

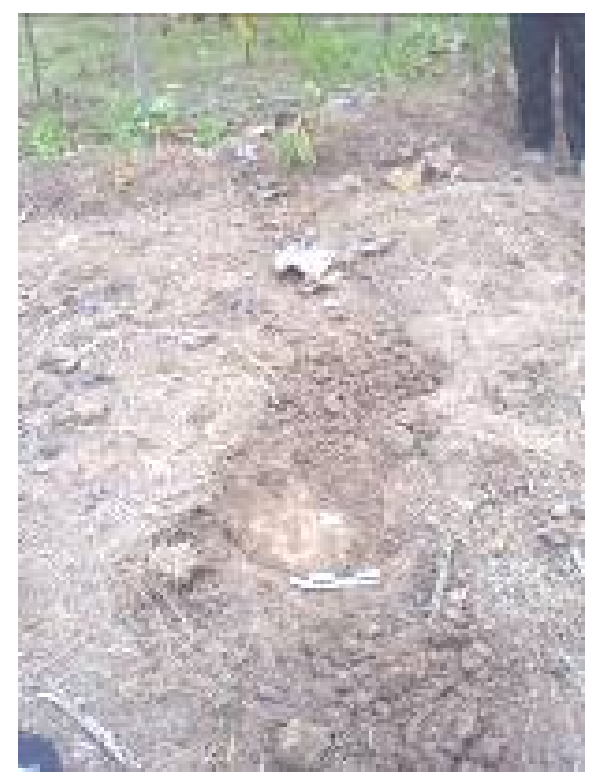

Gambar 2. Situs Brati

\section{Situs Pomahan}

Lokasi Situs Pomahan berada di Dusun Miyono, Desa Kayen, pada Koordinat S $06^{0}$ $54^{\prime} 24,7^{\prime \prime} \mathrm{E} 111^{\circ} 00^{\prime} 12.4^{\prime \prime}$, dan dpl $37 \mathrm{~m}$. Lokasi berada di tengah persawahan, dengan tanda alami terdapat Sungai Srombon di sebelah selatannya, berjarak kurang lebih $200 \mathrm{~m}$ dari candi diperkirakan ada struktur pagar. Setelah diadakan test-pit di permukaan tanahnya ternyata berupa tatanan batu berjumlah 3 susun/undakan. Tinggi undakan bata tersebut $32 \mathrm{~cm}$, ukuran salah satu bata yang masih utuh panjang $38 \mathrm{~cm}$, lebar $20 \mathrm{~cm}$, dan tebal $10 \mathrm{~cm}$.

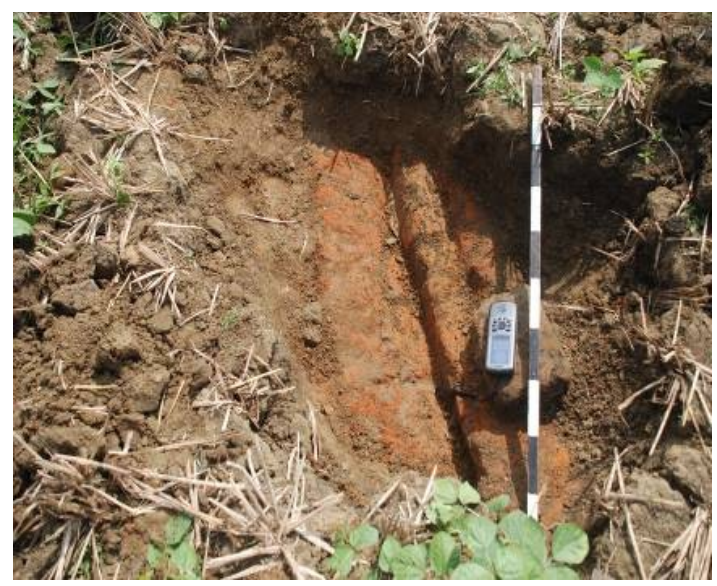

Gambar 3. Situs Pomahan

\section{LATAR BELAKANG PENDIRIAN CANDI}

Candi adalah bangunan kuna terbuat dari susunan batu andesit atau bata, didirikan sebagai tempat pelaksanaan upacara keagamaan bagi umat Hindu dan Buddha. Candi dibuat untuk menempatkan arca dewa yang dibuat sebagai sarana pemujaan, dan 
merupakan tempat bersemayamnya dewa yang arcanya ada di dalam bilik candi. Candi mempunyai makna simbolis sebagai alam semesta, terdiri atas 3 dunia, yaitu: pertama, dunia atas yang merupakan dunia para dewa, kedua, dunia antara yang merupakan tempat tinggal manusia, dan ketiga adalah dunia bawah yaitu dunia orang mati. Dunia atas tempat para dewa identik dengan puncak Gunung Mahameru yang dianggap sebagai gunung suci bagi masyarakat India. Juga Gunung Mahameru adalah gunung kosmos yang terletak di tengah kosmos dan menjadi poros dunia. Candi adalah replika dari Gunung Mahameru tersebut. Dewa-dewa akan turun ke bumi, dan berada di di dalam candi apabila dipanggil dalam suatu upacara, sedangkan hakekat candi adalah merupakan tempat pertemuan antara pemuja dengan dewa yang dipujanya. Fungsi candi kemudian berkembang menjadi tempat bersembahyangan untuk memuja dewa, dan menghormati nenek moyang. Dapat pula dikatakan, bahwa candi merupakan peninggalan dari masa Klasik Indonesia. Munculnya tidak pada awal perkembangan masa Klasik tersebut, melainkan sejalan dengan perkembangan kekuasaan secara kronologis kerajaan-kerajaan kuna. Hal ini dapat digolongkan menjadi 2 kelompok periode, yaitu:

1. Periode Jawa Tengah yang berkembang pada abad 8 Masehi sampai dengan abad 10 Masehi

2. Periode Jawa Timur meliputi kurun waktu abad 10 Masehi sampai dengan abad 15 Masehi.

Kedua periode tersebut mempunyai 2 kelompok gaya bangunan yang berbeda, yaitu gaya candi-candi Jawa Tengah dan gaya candi-candi Jawa Timur. Gaya Jawa Tengah oleh Santiko (1995) dinamakan juga gaya Mataram Kuna yang mengalami kejayaan sekitar abad 8 Masehi sampai dengan abad 10 Masehi.

Satu hal yang penting dalam pendirian sebuah candi adalah, penempatan titik pusat halaman candi serta kesucian areal candi. Di samping titik pusat halaman candi, juga tidak kalah pentingnya adalah titik pusat candi induk yang disebut Garbhagrha. Di bawah Garbhagrha dipendam sebuah peripih yang berisi benda-benda sebagai lambang dewadewa. Peripih sama dengan pendheman dalam aspek simbolis tradisi masyarakat Jawa umumnya, yaitu berupa persajian yang ditanam di dalam sumuran candi atau bagian candi lainnya, maupun di halaman candi. Tempat tersebut berupa kotak batu berlobanglobang kecil dengan jumlah ganjil. Lobang-lobang tersebut pada umumnya berjumlah satu lobang maupun sembilan lobang, yang disusun sebagai berikut: satu lobang di tengah, dan delapan lobang lebih kecil mengelilingi lobang pusat. Ke sembilan lobang melambangkan unsur Nawasangha yaitu sembilan dewa penguasa arah mata angin, dan yang terletak di tengah pusat adalah dewa Siwa. Lobang-lobang dalam peripih berisi sesuatu yang melambangkan dunia, seperti emas, perak, perunggu, batu akik, dan bijibijian. Adapula peripih yang berisi abu tulang binatang. Penanaman peripih ini berasal dari kebiasaan atau tradisi yang sampai sekarang masih ada. Hal ini dapat dilihat pada waktu akan membangun rumah/gedung, dilakukan penanaman objek upacara yang bertujuan menyucikan tempat tersebut agar terhindar dari segala yang jahat. Di dalam peripih adakalanya terdapat lempengan emas berbentuk teratai mekar (padma), kurakura, atau huruf /tulisan kuna yang berhubungan dengan mantra-mantra. Pada dasarnya peripih dimaksudkan untuk memberi daya penghidupan bagi candi (prana pratistha), serta mendapatkan restu dari para dewa. Di samping itu candi memiliki kekuatan gaib dan menjadikan bangunan candi sebagai rumah dewa yang pantas dipakai untuk pemujaan dewa-dewa (Santiko, 1995). Berdasarkan data dari para sarjana, diduga peripih tidak hanya ditempatkan di candi-candi Hindu, tetapi juga pada candi-candi Buddha (Hardiati, 2002).

Seperti telah diketahui, bahwa candi terdiri atas tiga bagian, yaitu:

1. Bagian paling bawah adalah kaki candi, biasanya dibuat lebih tinggi dari permukaan tanah dasar. Pada salah satu sisinya mempunyai susunan anak tangga atau undakan. Anak tangga tersebut bahannya bisa sejenis dengan bahan bangunan candinya. Seandainya tidak ditemukan struktur anak tangga dalam suatu ekskavasi, mungkin anak tangga terbuat dari kayu, yang tentunya kayu sudah tidak berbekas dalam kurun waktu sekian ribu tahun yang lalu. 
2. Di atas kaki candi terdapat tubuh candi, yang mempunyai bilik atau ruangan (garbhagrha), dan biasanya diisi oleh arca dewa. Pada candi Hindu, garbhagrha untuk pemujaan dewa Siwa terdapat lingga di atas yoni merupakan lambang Siwa, atau arca Siwa Mahakala.

3. Bagian paling atas adalah atap candi, terdiri atas tingkatan-tingkatan yang makin ke atas semakin mengerucut. Masing-masing tingkatan mempunyai hiasan berbentuk antefiks, kemuncak, atau miniatur candi. Bagian paling atas atap candi ditutup oleh bentuk kerucut (ratna) pada candi Hindu, dan stupa pada candi Buddha.

Sebuah candi pada umumnya tidak berdiri sendiri, melainkan lebih dari satu bangunan yang terdiri atas candi induk dan candi perwara. Jika terdapat beberapa candi induk dengan beberapa candi perwara dinamakan kompleks percandian, sebagai contoh Candi Prambanan, Kompleks Candi Dieng, dan Kompleks Candi Gedongsanga. Adapula bangunan candi induk dikelilingi oleh ratusan candi perwara seperti yang terdapat di Candi Sewu (Hardiati, 2002). Bagian luar candi ada yang dibatasi oleh pagar mengelilingi lokasi candi, tetapi ada pula yang tanpa pagar keliling. Biasanya bangunan candi-candi besar mempunyai pagar yang membatasi halaman candi, antara bagian halaman sakral dan profan. Soekmono, dalam disertasinya menegaskan bahwa candi adalah bangunan kuil sebagai tempat pemujaan dewa-dewa dan nenek moyang.

\section{ARSITEKTUR CANDI KAYEN}

Ekskavasi Candi Kayen berhasil menampakkan dua buah bangunan candi yaitu: Candi Induk dan Candi Perwara. Candi Induk berbentuk bujursangkar berukuran $5.9 \mathrm{~m} \mathrm{x}$ $5,9 \mathrm{~m}$, dan Candi Perwara berbentuk persegi panjang berukuran 4,6 m x 2,7 m. Berdasarkan data tersebut diduga, bahwa Candi Kayen hanya terdiri atas dua bangunan dengan masing-masing ukuran yang berbeda tersebut. Kedua bangunan ini tinggal bagian kaki, sedangkan tubuh dan atapnya sudah runtuh sehingga bentuk secara vertikal tidak dapat diketahui. Luas situs secara keseluruhan juga belum dapat diketahui. Pada penelitian sebelumnya salah satu tujuan adalah mencari pagar, dan diduga ditemukan di lahan Pomahan yang terletak kurang lebih 200 meter dari candi. Namun setelah dilakukan test-pit di wilayah tersebut, ternyata struktur yang nampak bukanlah struktur pagar, bahkan merupakan struktur bangunan. Dugaan bahwa struktur pagar candi ada di wilayah itu kurang tepat, jadi untuk sementara luasan situs Candi Kayen belum dapat diperkirakan.

Candi Induk berdenah bujursangkar, pada sisi timur - selatan dapat dilihat bahwa pada tiga lapis terbawah nampak melebar ke luar selebar $9 \mathrm{~cm}$. yang fungsinya untuk memperkuat bagian fondasi bangunan. Di sudut timur-laut bangunan candi, apabila komponen batanya masih ada, saat ini berada di bawah fondasi serambi musholla. Sisi barat, terdapat struktur anak tangga berupa 6 lapis bata yang masih intact dengan orientasi utara-selatan. Anak tangga ini tampaknya merupakan pintu masuk ke bilik Candi Induk, mempunyai ukuran lebar $51 \mathrm{~cm}$ terdiri atas 3 susunan bata. Salah satu diantara susunan bata ini terdapat sebuah batu putih dengan ukuran tebal $9 \mathrm{~cm}$, dan lebar $25 \mathrm{~cm}$. Dalam arsitektur bangunan candi kedua bahan itu juga sering digunakan secara bersama. Tepat di tengah-tengah candi Induk, menurut keterangan penduduk pernah digali oleh orang yang tidak bertanggungjawab. Penggalian liar tersebut selain lewat sisi selatan, juga melewati sisi timur dengan mengangkat bata-bata yang masih intact. Sehingga sisi struktur sudut timur-laut banyak yang hilang, meskipun ujung sudut masih dapat dilacak. Pada bagian tengah sisi selatan, di antara susunan bata nampak adanya rongga seluas $66 \mathrm{~cm}$ yang sekarang ditutup dengan tanah. Rongga tersebut nampaknya sengaja dibuat oleh penggali liar, yang menduga bahwa di tengah-tengah bangunan candi itu terdapat harta karun. Rupa-rupanya mereka tidak dapat mengembalikan susunan batanya seperti semula, sehingga mereka tambal dengan tanah. Hal ini menyebabkan, dinding selatan bangunan candi melesak ke bawah. Demikian pula pada 
sisi utara, sudah mengalami kerusakan karena pernah digali dan dibongkar seluruh lapisan batanya.

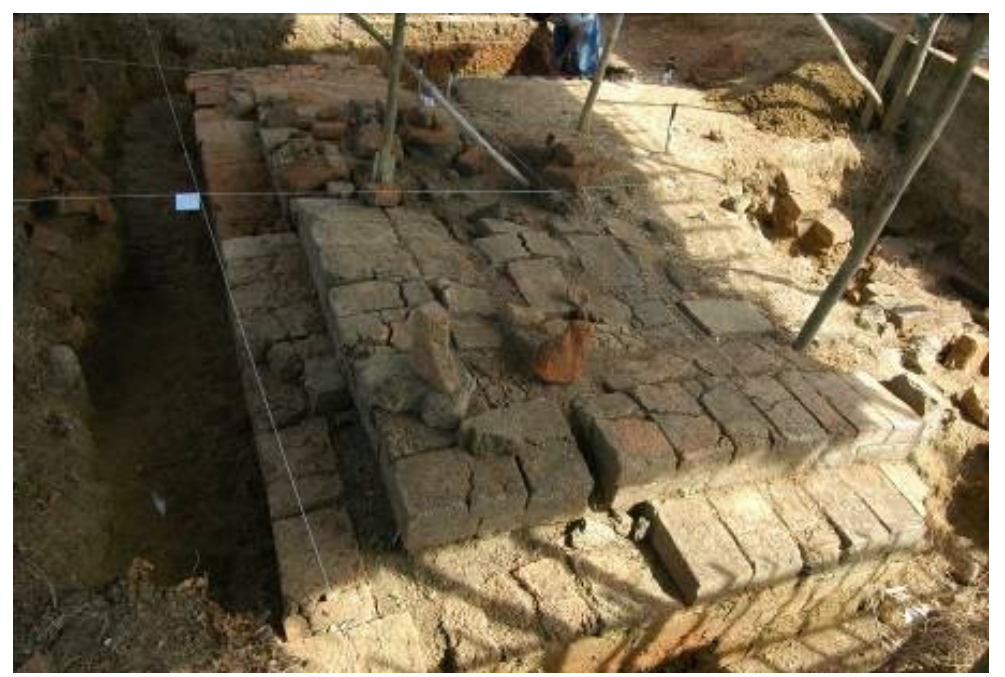

Gambar 4. Candi Induk hanya tersisa bagian kaki candi saja, setinggi kurang lebih $70 \mathrm{~cm}$ dari dasar tanah. Berdasarkan ekskavasi sejumlah 3 kotak galian di Candi Induk, ditemukan runtuhan bata yang cenderung runtuh ke arah selatan, disamping temuan lain berupa kemuncak, dan antefiks candi. Kemuncak dan antefiks biasanya menghiasi bagian atap candi.

Hal ini menunjukkan bahwa kemungkinan dahulu candi utuh mempunyai kaki, tubuh, dan atap candi. Karena pernah dilakukan penggalian liar dan pengambilan batabata untuk bangunan lain, maka sisa-sisa tubuh dan atap candi sama sekali tidak ditemukan. Kemungkinan lain, yaitu candi memang tidak mempunyai atap candi, karena atap terbuat dari kayu yang mudah lapuk. Tetapi kemungkinan ini jauh dari perkiraan tersebut, karena apabila atap terbuat dari kayu tentunya akan ditemukan umpak atau lobang pada kaki candi tempat kayu tersebut didirikan. Hal tersebut tidak ditemukan di Candi Kayen, jadi yang mendekati kebenaran adalah dugaan yang pertama.

Berdasarkan anak tangga yang terdapat di sisi barat menunjukkan bahwa Candi Kayen menghadap ke arah barat, berhadapan dengan Candi Perwara. Bahan candi yang terbuat dari bata, kemungkinan karena tanah disekitar lokasi candi baik untuk membuat bahan bata. Bata merupakan salah satu material yang baik dan layak digunakan untuk pendirian bangunan-bangunan suci. Sebab selain cukup kuat dan tahan lama proses pembuatannya tidak terlalu sulit, tidak mengeluarkan tenaga banyak, dan lebih menghemat biaya. Hal ini didukung pula oleh tersedianya bahan yang cukup dan teknologi pembuatan bata yang sudah dikenal dengan baik. Tanpa pengenalan teknologi yang memadai, bahan yang tersedia cukup melimpah tidak akan dimanfaatkan dengan baik.

Kotak ekskavasi di Candi Perwara berjumlah 4 kotak ditentukan dengan pertimbangan dapat menampakkan seluruh bangunannya. Ke empat sudut sudah ditemukan, dengan demikian dapat diketahui Candi Perwara berbentuk persegi panjang, permukaan atas berupa remukan bata yang mengeras. Dinding sisi selatan tampak susunan 8 lapis bata, namun dinding sisi utara hanya nampak 4 lapis bata saja. Memang Candi Perwara kelihatan miring dan melesak di sisi utaranya. Temuan sangat sedikit, di samping runtuhan bata yang tidak kondusif, juga ditemukan dua kemuncak dan satu buah antefiks. Tampaknya Candi Perwara dibuat tidak bersamaan periodenya dengan candi Induk. Melihat ukuran batanya yang rata-rata lebih kecil dibandingkan dengan ukuran bata Candi Induk. Ukuran bervariasi antara panjang $23 \mathrm{~cm}-26 \mathrm{~cm}$, lebar $21 \mathrm{~m}-24$, dan tebal $7,5 \mathrm{~cm}$, sedang ukuran bata Candi Induk bervariasi antara panjang $39 \mathrm{~cm}-41 \mathrm{~cm}$, lebar $23 \mathrm{~cm}-25 \mathrm{~cm}$, dan tebal $10 \mathrm{~cm}-11 \mathrm{~cm}$. Ada beberapa candi yang dibangun tidak 
dalam satu periode, bahkan berselang sampai ratusan tahun kemudian. Fungsi bangunan ini diperkirakan tempat menaruh sesaji sementara sebelum dipersembahkan ke dalam Candi Induk.

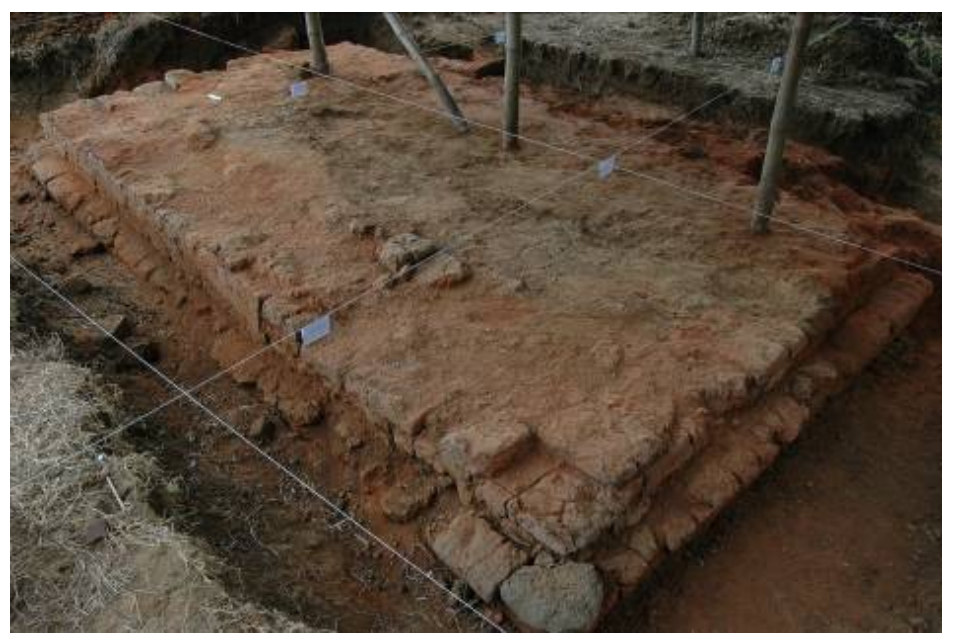

Gambar 5. Demikian pula pada Candi Perwara, hanya tersisa bagian kaki candi saja. Bangunan Candi Perwara terletak berhadap-hadapan dengan Candi Induk, menghadap ke arah timur, dan tidak mempunyai tangga.

Selanjutnya dibuka kotak B10 U7, yang terletak agak jauh dari ke dua bangunan candi tersebut. Kotak ini berada di sebelah utara horizontal dengan candi Perwara. Pada penelitian tahap I diperkirakan candi perwara ada 3 buah, oleh karena itu perlu dibuktikan kebenarannya. Kotak dibuka sampai dengan spit 3 atau pada kedalaman $60 \mathrm{~cm}$ ternyata tidak ada struktur bangunan maupun temuan lainnya. Jadi diasumsikan bahwa Candi Perwara memang hanya ada satu buah, sesuai dengan ukuran. Candi Induknya yang relatif tidak begitu besar.

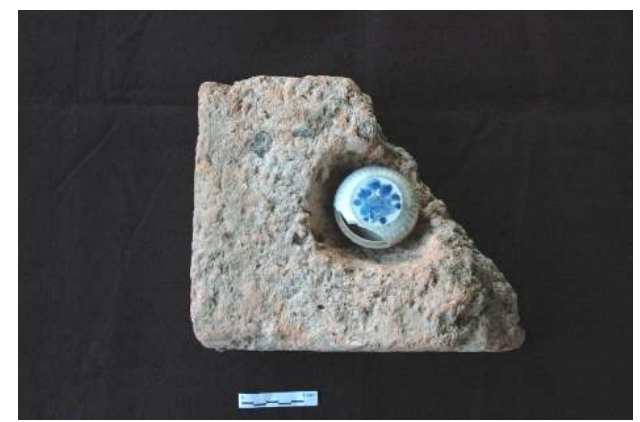

Gambar 6. Batu peripih dari bata, yang di dalamnya berisi cepuk keramik, berasal dari sumuran di kaki candi, sekarang disimpan di rumah penduduk

Salah satu hasil penggalian liar yang sekarang disimpan penduduk, berupa peripih berbahan bata, dengan lekukan di tengah, dan di dalamnya berisi cepuk terbuat dari keramik terdiri atas dua bagian, wadah dan tutupnya. Cepuk berwarna putih dengan ornamen bunga-bunga berwarna biru berasal dari Cina. Menurut keterangan penduduk yang menyimpannya, ketika ditemukan di dalam cepuk terdapat abu yang ... ???ditutup lembaran emas. Abu di dalam cepuk yang disangka hanya kotoran tanah biasa, oleh penemunya kemudian dibersihkan dan dibuang. Padahal peripih biasanya berisi syaratsyarat sesaji untuk pembangunan sebuah candi. Isi tersebut dapat diketahui dengan cara analisis di laboratorium meskipun sudah berupa tanah, dan nantinya akan dapat diketahui komponen-komponen apa yang terdapat di dalam peripih tersebut. 
Temuan lain yang menurut penduduk berasal dari situs Candi Kayen adalah arca Siwa Mahakala dari batu putih (limestone). Sayangnya arca tersebut telah dilapisi semen, karena menurut pikiran mereka, arca akan lebih awet dari kerusakan kalau disemen. Hal ini justru merusak arca, menyebabkan atribut-atribut arcanya tidak jelas.

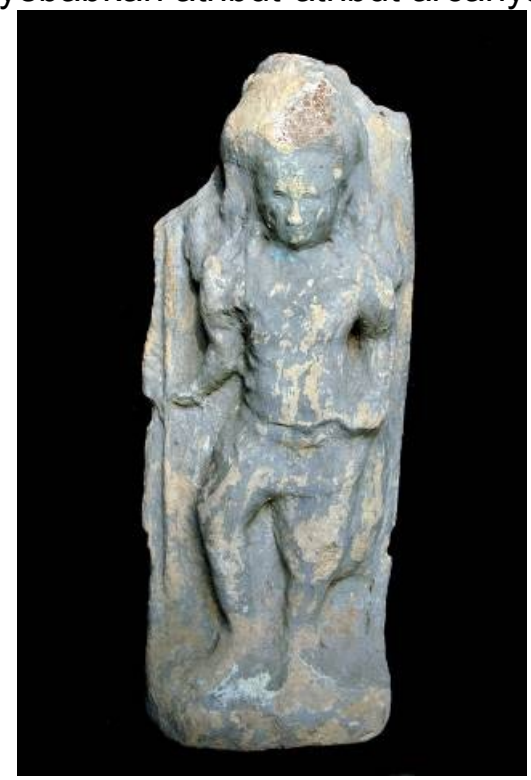

Gambar 7. Arca Siwa Mahakala dari batu putih

Sekarang arca ini disimpan di rumah Bapak Abdul Wachid sesepuh Desa Kayen bersama dengan temuan lepas lainnya. Dalam candi Hindu, Siwa Mahakala ditempatkan di ruang utara atau berupa lingga di atas yoni yang merupakan lambang dewa Siwa. Pada ruangan atau relung-relung yang terdapat di bagian tubuh candi, ditempatkan arcaarca pantheon dewa Siwa untuk pemujaan kepada dewa Siwa. Pantheon itu adalah, Ganesha di arah belakang pintu masuk, Durga di sebelah dinding utara, dan Agastya di sebelah dinding selatan. Candi Kayen belum dapat dipastikan dibuat untuk pemujaan kepada siapa. Namun melihat temuan arca Siwa Mahakala tersebut - apabila memang benar ditemukan di lokasi candi - kemungkinan untuk pemujaan dewa Siwa, meskipun kemungkinan ini masih jauh dari perkiraan, mengingat minimnya data-data pendukung yang ditemukan. Temuan lepas lainnya yang sekarang disimpan penduduk, berupa fragmen keramik, fragmen tembikar, alat-alat rumah tangga dari perunggu (talam, mangkok, guci, piring, tangkai cermin (darphana) dan sebagainya. Fragmen-fragmen tersebut karena ditemukan bukan pada saat dilakukannya penelitian tahap II ini, maka tim tidak dapat memastikan kebenarannya karena sudah kehilangan konteks temuannya.

\section{PENUTUP}

\section{Kesimpulan}

Penelitian selama 2 tahap di Candi Kayen, telah berhasil menampakkan seluruh kaki Candi Induk dan Candi Perwara. Kesimpulannya adalah candi berlatar belakang agama Hindu, berbahan bata, di mana candi-candi bata masih langka di kawasan pantai utara Jawa Tengah.. Candi berbahan bata menunjukkan bahwa di kawasan sekitar candi tersebut, menyediakan bahan yang cukup dan tanah yang bagus untuk membuat bata, meskipun secara teknis unsur bata lebih mudah rusak dibandingkan batu andesit. Oleh karena itu sebagian besar candi bata di Jawa Tengah ditemukan dalam keadaan tidak utuh lagi. Temuan lepas seperti fragmen keramik dan cepuk peripih dari keramik Cina, menandakan bahwa pada masa candi tersebut dibuat, masyarakatnya sudah melakukan hubungan perdagangan dengan dunia luar. Di samping alat-alat rumah tangga yang terbuat dari gerabah, mereka juga menggunakan benda-benda keramik dari luar. Sebagaimana diketahui, bahwa bangsa Indonesia pada masa Klasik belum dapat 
membuat benda-benda dari keramik. Bahan keramik belum diketahui, dan yang banyak tersedia adalah tanah liat, bahan-bahan untuk pembuatan gerabah.

\section{Saran}

1. Karena luas situs Candi Kayen belum ditemukan, perlu penelitian lebih lanjut di tahun mendatang.

2. Penelitian candi-candi bata di Jawa Tengah sangat penting mengingat kelangkaan situs.

3. Mudah rusaknya bahan bata diperlukan upaya-upaya pelestarian terhadap situs-situs candi bata yang masih dapat ditelusur denahnya. Hal ini untuk menjaga agar candi bata tersebut tidak punah di telan waktu.

4. Selama ini Kabupaten Pati dikenal dengan banyaknya peninggalan-peninggalan masa Islam sebagai wisata religi. Dengan ditemukannya Candi Kayen, Kabupaten Pati juga memiliki potensi cagar budaya tinggalan Masa Klasik atau Masa Hindu yang perlu dipublikasikan kepada masyarakat luas.

\section{KEPUSTAKAAN}

Acharya, Prasanna Kumar. 1993. Archietecture of Manasara. London: Oxford University.

Boechari, 1978. Bahan Kajian Arkeologi Untuk Pengajaran Sejarah, Majalah Arkeologi Th. II No. 1. Jakarta: FS UI

Hardiati, Endang Sri. 2002. Aspek Arsitektural dan Aspek Simbolik Bangunan Candi. Candi. Sebagai Warisan Seni dan Budaya Indonesia. Yogyakarta: Yayasan Cempaka Kencana. Gadjah Mada University Press. Halaman 1-14.

Istari, TM. Rita.. 2011. Laporan Peninjauan: Situs Kayen, Dusun Miyono, Desa Kayen, Kecamatan Kayen, Kabupaten Pati. Yogyakarta: Balai Arkeologi Yogyakarta

Mundardjito, 1993. Pertimbangan Ekologi Dalam Penempatan Situs Masa Hindu-Buddha Di Daerah Yogyakarta: Kajian Arkeologi Ruang Skala Makro. Disertasi. Jakarta: Universitas Indonesia.

Santiko, Hariani. 1995. Seni Bangunan Sakral Masa Hindu-Buddha di Indonesia (Abad VIII - XV Masehi): Analisis Arsitektur dan Makna Simbolik. (Pidato Pengukuhan Guru Besar). Jakarta: Universitas Indonesia.

Soekmono. 1974. Candi, Fungsi dan Pengertiannya. (disertasi Doktor dalam IImu dan Sastra). Jakarta: Fakultas Sastra Universitas Indonesia.

Kramrisch, Stella. 1949. The Hindu Temple Vol. I. Calcutta: University of Calcutta.

Tjahjono, Baskoro Daru. 2002. Latar Belakang Pendirian Candi Bata di Jawa Tengah. Laporan Penelitian Arkeologi. Yogyakarta: Balai Arkeologi Yogyakarta.

Tjahjono, Baskoro Daru. 2003. Harta Karun Itu Candi Bata Yang Unik. Berkala Arkeologi Th. XXIII (2) Nov. 2003. Yogyakarta: Balai Arkeologi Yogyakarta. 